\title{
Wooden foundations history and prospects
}

\author{
Lyudmila Cherkasova ${ }^{1, *}$ \\ ${ }^{1}$ Moscow State University of Civil Engineering, Yaroslavskoe sh. 26 Moscow, Russia
}

\begin{abstract}
Wooden foundations have been in use since ancient times. With the advent of new materials and technologies they have been almost completely driven out of building practice. The main disadvantage of such foundations is their short service life. However, there are historical examples in which wooden foundations had been used for hundreds of years. In the opinion of the author, if comply with proper rules of operation, wood can be effectively used as foundation and for foundation strengthening in modern foundation engineering.
\end{abstract}

\section{Introduction}

Wooden foundations have a long history in European and Asian countries. In Russia such foundations initially were used only for wooden buildings. Builders were aware that the wood in the ground in a fluctuating moisture area is the most prone to rotting, that is why groundsills that were replaced or removed after loosing bearing capacity were used as girder foundations. An example would be a church in the village of Ljavlja [1] that is more than 400 years old. As a result of the gradual removal of groundsills the Church lost $4.5 \mathrm{~m}$ of height.

Foundation posts often were made of tree stumps that had the toughest wood. Posts were used for small houses (hut on "chicken legs") and large ones like Ostankino Palace [2], where it was quite difficult to replace girder foundations.

In Russia, foundations were made mainly of coniferous resinous wood as they are prone to rotting less than others, however, longevity was not the primary requirement for foundation design. The main advantage of the wooden foundations was that they were relatively easy to replace without destroying the building.

Wooden piles were often used in marshlands where peaty compressible soils are used for foundation.

For stone constructions foundations where wooden elements were united by rubblework were not intended to be replaced or repaired were built [3]. That is why builders tried to abide by the basic rule for keeping longevity: elements of the foundations must always remain under water. In those cases where this rule was observed buildings have been standing for hundreds of years. Construction on wooden piles was widespread in Holland and Italy (Venice). European experience has been used during the construction of St. Petersburg and spread over Russia. Wooden elements in complex foundations had

\footnotetext{
*Corresponding author: CherkasovaLI@mgsu.ru
} 
several functions: transmission of loads to denser layers of foundation and sealing with wooden piles - Kazan Cathedral on Red Square, stress equalization in foundation under rubblework boulders (for this horizontally laid logs called sills), compression of the weak layer directly under the raft foundation of massive buildings - Saint Isaac's Cathedral, during the construction of which more than 11000 piles has been driven in. There are 40000 piles under the Peter and Paul Fortress. These foundation still retain the bearing capacity.

For comparison, in Venice more than a million oak, alder, hardwood piles are driven in the foundation of the Santa Maria della Salute Church; the Rialto Bridge stands on 12 thousands of stone piles

Alexander Nevsky Cathedral in Nizhny Novgorod is a unique historical example. The massive building, comparable in size to Saint Isaac's Cathedral in Saint Petersburg, is built on the arrow at the confluence of the rivers Oka and Volga. A raft of $3 \mathrm{~m}$ thick oak logs is laid on weak water saturated foundation. The raft is immersed in a bath of fat clay to prevent wood from drying out and rotting. The cathedral, built over 150 years ago, is still used, and its foundations successfully perform their function. The Royal Palace in Amsterdam stands on 13659 piles

Pile wood foundations are used in construction of coastal structures or directly on water.

\section{Modern Wooden Foundations}

Modern wooden foundations are used primarily for traditional structures of country architecture, cottage buildings and small temporary structures. Durability of foundations is extended due to treatment with chemicals and external tarring of logs and bases of buildings (Holland). However, the recommended service life of such buildings should not exceed 10-30 years. Usually pier foundation are constructed, in trenches. Sometimes girder foundation are an available option. The reason for low durability of the proposed foundations lies in their design that typically includes elements in area of soil foundation with a variable level of ground waters.

In construction wood is also used for pile planking of excavation shoring. In modern construction practice wood, as an element reinforcing weak water saturated soils, is almost never used.

Meanwhile, natural durability of logs completely immersed in water and their light weight make wood the most suitable material for reinforcement of weak water saturated soils.

Some wood species not only do not lose, but even gain strength while underwater. Light material almost does not weigh down the weak layer, preventing differential settlement. The specific gravity of pine, even in water-saturated condition, does not exceed the specific gravity of water. Since there is no need to bury pile ends in more durable soils, they can be submerged by the overloading method. Thus eliminates the negative impact of dynamic effects on nearby foundations. Finally, you should take into account the high ecological value of wood. After the use and dismantling of overfoundation structures usable area suitable for further exploitation remains. 


\section{Comparative ANALYSIS OF VARIOUS METHODS FOR FOUNDATION STRENGTHENING UNDER THE FLOOR OF A WAREHOUSE ON WEAK WATER-SATURATED GROUND}

\subsection{Description of the Geological Conditions, Structure design and Options for Foundation Strengthening}

The warehouse built in the floodplain of the river Yakhroma stands on reinforced concrete plate $30 \mathrm{~cm}$ thick on sand-and-gravel cushion $0.5 \mathrm{~m}$ thick. The floor plate is loaded with strip load $5.5 \mathrm{t} / \mathrm{m}^{2}$. Load can be changed during operation. Plate dimensions are $36 \times 114 \mathrm{~m}$.

The base is made of fill grounds (EGE 1,2) with a capacity of 2.5-3.1 m, under which peaty soils are laid (EGE 3 ) of variable capacity 1.9-2.5 m. Below a layer of plastic sand clay (EGE 4) of average capacity $4.6 \mathrm{~m}$, under which a mass of fine sand of average density EGE 5 and non-determined capacity is located. Minimum groundwater level is set to 134.0. Level of leveled surface is $134.7 \mathrm{~m}$ (fig.1.).

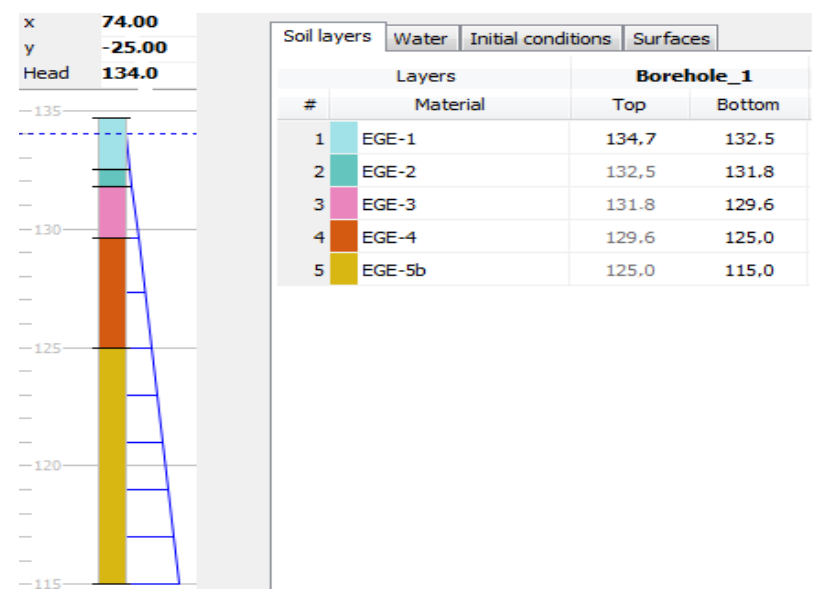

Fig. 1. Geologic column with averaged data on layers's capacity.

After commissioning and loading the project load with following transfer of it wavelike deformation of the floor has been identified, precluding its normal operation and moving of lifting devices.

During development of the method of base reinforcement and reconstruction of the warehouse floor two options were compared.

Option 1. Driving piles of reinforced concrete in sand foundation layer through holes in the floor with the subsequent dismantling and repetition of floor covering works.

Option 2. Pressing-in of wooden piles through holes in the floor with the subsequent dismantling and repetition of floor covering works. Wooden piles are pressed in in such a way so that their heads were at $0.5 \mathrm{~m}$ below the minimum water level and cut through the peaty soil layer without immersion into dense sand. Pile heads are covered with sand $0.5 \mathrm{~m}$. A layer of sand is also laid $0.5 \mathrm{~m}$ above pile heads (fig. 2). 


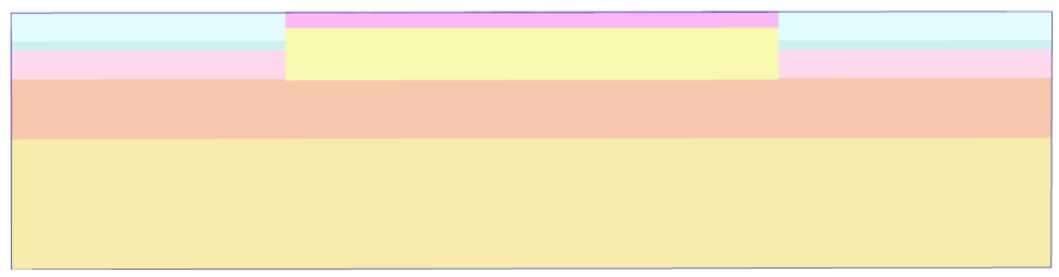

Fig. 2. Geological section with the mass of the layer compacted by wooden piles (option 2).

\subsection{Target Setting. Calculation Results}

The goal of calculation was a qualitative comparison of the options, so in the first approximation, influence of the existing pile foundations under the columns of the building was not analyzed. The floor plate is loaded with strip load. Calculated diagram of presented in the fig. 3 .

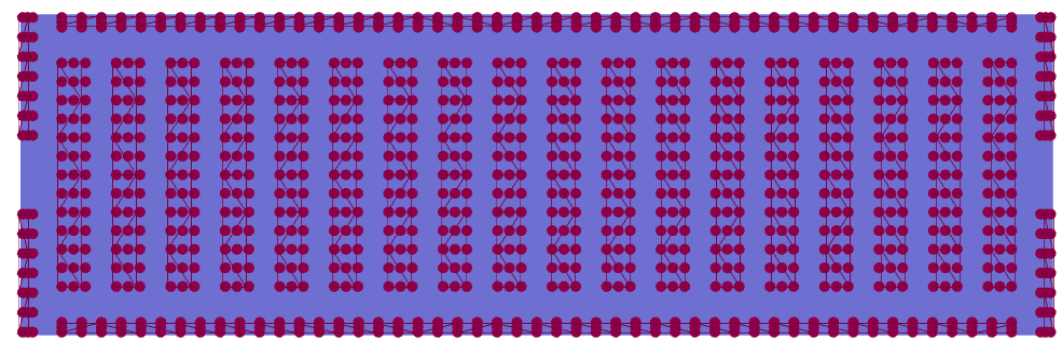

Fig. 3. Diagram of loading the slab of the warehouse floor with strip load.

Option 1. The length of the piles was determined by driving piles into the layer of sand on $0.5 \mathrm{~m}$, embedding heads at the floor level and was $8 \mathrm{~m}$. It should be noted that driving of the 8 -meter drive piles indoors was complicated by the need to use composite piles.

Piles space is chosen, basing on project load, on a simple square grid $2.65 \times 2.65$

Option 2. Wooden piles $4 \mathrm{~m}$ long are pressed in on a triangular grid with the space $2 \mathrm{D}$ (opt.2a) and $3 D$ (opt 2b). Choice of pile space was based on the condition of determination of the provided modulus of deformation according to the formula (1) [4].

$$
E_{\mathrm{pr}}=\left(S_{\mathrm{br} /} S_{\mathrm{ach}}\right) \cdot E_{\mathrm{d}}=[\pi /(2 \cdot \sqrt{3})] \cdot(D / X)^{2} \cdot E_{\mathrm{d}}
$$

where $E_{\text {пр }}$ - is a provided modulus of soil foundation with wooden piles;

$E_{\mathrm{d}}-$ wood deformation modulus;

$X$-distance between the piles;

$D$ - diameter of a wooden pile m;

$S_{\text {br. }}-$ pile cross-sectional area;

$S_{\text {ach }}$ - low-level cell area including the pile and surrounding soil.

When positioning the logs with the space $X=2 D$ provided module is $E_{\mathrm{pr}}=2724.25 \mathrm{MPa}$.

When positioning the logs with the space $X=3 D$ provided module is $E_{\mathrm{pr}}=1212 \mathrm{MPa}$.

During calculations the deformation module of weak soil is not taken into account.

In the first approximation, we consider: mass compacted by wooden piles as a linear elastic isotropic solid element with provided deformation module $E_{\mathrm{pr}}=1212 \mathrm{MPa}$ and $E_{\mathrm{pr}}=$ 2724.25 MPa, volume weight $15 \mathrm{kN} / \mathrm{m}^{3}$, with Poisson's ratio $v=0.4$. Diameter of piles $D=$ is $0.25 \mathrm{~m}$. Compacted mass thickness is $4 \mathrm{~m}$. 
The task was solved in three-dimensional setting with maximum simplification of the original data. The purpose of the calculation is to figure out qualitative differences, advantages and disadvantages of 2 options of weak layer fortification.

Determination of maximum, minimum vertical deformation and settlement difference are held for calculation cases.

1. Without strengthening of the foundation

2. After strengthening of the foundation with reinforced concrete piles

3. After reinforcing weak layer with wood piles with the space $3 D$.

4. After reinforcing weak layer with wood piles with the space $2 D$.

The results are listed in the Table 1.

Table 1. Results of determination of vertical deformations of floor slab for various options of foundation reinforcement.

\begin{tabular}{|c|l|c|c|c|}
\hline $\begin{array}{l}\text { Case } \\
\text { Nos. }\end{array}$ & $\begin{array}{c}\text { Strengthenin } \\
\text { g the } \\
\text { foundation }\end{array}$ & $\min [\mathbf{c m}]$ & $\max [\mathbf{c m}]$ & $\Delta=(\max -\min ) / \mathbf{L}$ \\
\hline 1 & $\begin{array}{l}\text { Without } \\
\text { foundation } \\
\text { strengthening }\end{array}$ & 1.4 & 8.9 & 0.0042 \\
\hline 2 & Piles r.-c. & 0.40 & 1.66 & 0.0007 \\
\hline 3 & $\begin{array}{l}\text { Wooden piles, } \\
\text { space 3D }\end{array}$ & 0.56 & 1.29 & 0.0004 \\
\hline 4 & $\begin{array}{l}\text { Wooden piles, } \\
\text { space 2D }\end{array}$ & 0.65 & 1.23 & 0.0003 \\
\hline
\end{tabular}

Comparative analysis of 2 main reinforcement options: of reinforced concrete and wooden piles is listed in the Table 2 .

Table 2.

\begin{tabular}{|c|c|c|c|c|c|}
\hline $\begin{array}{c}\text { Type } \\
\text { of } \\
\text { reinforcem } \\
\text { ent }\end{array}$ & $\begin{array}{c}\text { Number } \\
\text { and } \\
\text { length) } \\
\text { of piles }\end{array}$ & $\begin{array}{c}\text { Dynamic } \\
\text { al loads }\end{array}$ & $\begin{array}{c}\text { Creation } \\
\text { of sand } \\
\text { gravel } \\
\text { layer }\end{array}$ & $\begin{array}{c}\text { Settlement } \\
\text { under load, } \\
\text { cm }\end{array}$ & Service life \\
\hline $\begin{array}{c}\text { R.-c.piles } \\
\text { (length 8m) }\end{array}$ & 575 & $\begin{array}{c}\text { Yes } \\
\text { (driving } \\
\text { in) }\end{array}$ & $0.3 \mathrm{~m}$ & 1.65 & Not limited \\
\hline $\begin{array}{c}\text { Wooden } \\
\text { piles } \\
\text { (ength 4m) }\end{array}$ & $\begin{array}{c}18552 \\
\text { (space } \\
2 D) \\
8245\end{array}$ & $\begin{array}{c}\text { No } \\
\text { (pressing- } \\
\text { in) } \\
\text { (space } \\
3 D)\end{array}$ & $1.0 \mathrm{~m}$ & 1.29 & $\begin{array}{c}\text { Limited to } \\
\text { maintenance of } \\
\text { the groundwater } \\
\text { level. }\end{array}$ \\
\hline
\end{tabular}

\section{Conclusions}

In case of reinforcement with wooden piles settlement is less pronounced and more even than in case of reinforcement with r.c. piles. The cause is the more frequent driving and low density of the piles themselves.

Wooden pile space $(2 D$ or $3 D)$ does not affect the degree and uniformity of deformations significantly. 
Dynamic loading, which is dangerous at works in the constrained environment, can be excluded at driving wooden piles. Wooden piles are pushed into the soft ground. Driving them into sand is useless.

Construction site area is available in case of dismantling of structure. Wooden piles do not interfere the new constructions.

\section{References}

1. M.V. Korolev, L.I. Cherkasova, A.V. Ostiakova, Specifics of Inspection and Restoration of Orthodox Churches (MGSU, Moscow, 2016)

2. L.I. Cherkasova, G.V. Alekseev, E.A. Medvedev, Vestnik MGSU 1, 170-173 (2006)

3. V.A. Il'ichev, N.S. Nikiforova, V.V. Dmitriev, S.V. Devyatov, T.D. Shvets, E.Kostyukov, Soil Mechanics and Foundation Engineering 53(3), 180-188 (2016)

4. I.I. Khusainov, The design of the "structural geomassiv" in difficult geological conditions. The dissertation on competition of a scientific degree candidate of technical Sciences. The specialty 05.23.02 "Bases and foundations, underground structures" (Perm National Research Polytechnic University, Perm, 2015) 